\title{
Trabajo Decente? \\ Decent Work from a Cuban Perspective
}

\author{
Osnaide IZQUIERDO ${ }^{1}$, Nina JANY² \\ Universidad de La Habana
}

\begin{abstract}
In this article, we critically examine Cuban social and labour policies as attempts of a practical application of Decent Work principles in a state-socialist context. We start with an examination of past and present models of socio-economic development and labour relations in Cuba. This is followed by an overview of the main Cuban policy principles related to Decent Work, which we contrast with some developments in $\mathrm{Cu}$ ban labour realities. To contextualize our analysis, we emphasize the conceptualizations of work, production and property, as well as the institutional logics that underly the Cuban labour models and policies. Finally, two policy areas are highlighted by way of example: wages and gender equality.
\end{abstract}

Keywords: Cuba, decent work, labour relations, wage policy, gender equality

\section{Introduction}

In the 1944 Declaration of Philadelphia, a document that is often mentioned as a predecessor of the concept of decent work, the International Labour Organization (ILO 1944: 1) states as one of its fundamental principles that "labour is not a commodity". However, following the official proclamation of the ILO's Decent Work Agenda (DWA) in 1999, this agenda has been criticized for its narrow conception of work by focusing on core labour standards and endorsing business self-regulation and supply-side economics (for an overview of such criticism, see Hauf 2015). Subsequently, the ILO committed to extending these standards and to moving towards a broader conception of work, intending to include, for instance, informal labour and care work. This broader definition, as it is put forward by the ILO today, places slightly more emphasis on a social dimension of work. Nonetheless, the DWA still seems to deviate from its original aim

\footnotetext{
${ }^{1}$ Dr. Osnaide Izquierdo (osnaide@ffh.uh.cu) is a professor, researcher and head of the Department of Sociology at the University of Havana/Cuba.

${ }^{2}$ Nina Jany (nina.jany@unifr.ch) is a doctoral researcher in the Department of Social Policy, Social Work and Global Development at the University of Fribourg/Switzerland and in the Department of Sociology at the University of Havana/Cuba.
} 
"to reduce the commodity character of labour relationships" (Standing 2008: 258), and to lack a critical stance on the ever-increasing emphasis on the commodification and marketization of labour in the $21^{\text {st }}$ century. Drawing on former critiques of the decent work concept in this regard (e.g., Standing 2008, Izquierdo 2017), we in this article argue that work should be considered first and foremost as a social category. As a consequence, we suggest that to analyse the decency of labour policies and realities, it is important to consider the relations of labour, production and property underlying such policies.

In the following, we will do so with the example of the historical development and current situation of social and labour policies and actual working conditions in Cuba. Since the 1960s, the Cuban state has promoted a wide range of principles associated with the concept of decent work. However, the reality of past and especially of present Cuban working conditions only partly reflects and realizes these principles. The first section of this article introduces and discusses the - past and present - conceptual framework of the Cuban models of socio-economic development and labour relations. This is followed by an overarching analysis of Cuban labour and employment policies in the second section, focusing on these policies' key principles that are associated with the concept of decent work. We contextualise the analysis of the Cuban models and their principles by emphasizing underlying conceptions of work, relations of production and property, as well as the (in)congruency of labour policies with institutional foundations and logics. Finally, we focus in more detail on the examples of wage policy and gender equality measures as two areas in which political claims and the principles of decent work seem to be particularly at odds with everyday realities in Cuba.

In the conclusion, we briefly summarize our analysis and reflect on the importance of a critical stance when assessing labour policies and realities in the contemporary realm of work, also beyond the Cuban case. Finally, we consider some possible future developments and approaches for solutions that would enable more decent working conditions in Cuba.

\section{The Cuban Models of Socio-Economic Development and Labour Relations}

After the seizure of political power in 1959, the Cuban revolutionary government opted for a centralist formula based on the empowerment of the state as the leading institution of economic development and guarantor of justice and social welfare. This recourse to a centralist type of governance was justified by a development strategy oriented towards accelerated industrialization, agricultural diversification, internal income redistribution and the reorientation of international economic relations. A large and dominant state sector was created, which at that point became the main actor in the Cuban economy, covering nearly all of its branches. This process (in the following referred to as stateization process) guaranteed the state monopoly on resources and their distribution. The process was based on a structure of planning, administration and distribution of power that legitimized and facilitated centralized and hierarchical decision-making on these state resources, leaving very little space for market mechanisms.

Over time, the Cuban development model was gradually adapted to the model that had been institutionalized in other socialist countries. It was based on a property system in which social property mainly took the form of state ownership. The adherence to this model during the most 
critical moments of Cuba's history ${ }^{3}$ has, to a certain extent, ensured the rights of the working class, but was, at times, also accompanied by high socio-economic costs. Admittedly, the model and its institutions have since then transformed, especially regarding the institutional changes starting in 2011. With the so-called update of the Cuban socio-economic model, a far-reaching (and still ongoing) reform process was started, which seems to mark a new trend for Cuban socio-economic development. The Cuban state, as the leading institution and guarantor of people's rights and social welfare, has unquestionably begun to share responsibilities in the areas of societal production, investments, employment, marketing and the provision of certain services to the population.

However, it would be simplistic to think of these changes as a linear transformation process away from state planning and towards the liberalization of market action. According to the reformers themselves, it is better described as a slow and calculated action which first and foremost seeks greater levels of economic efficiency. Simultaneously, in the long term, the reforms should rather consolidate the state's role as the central institution that determines the rules of insertion, negotiation, and empowerment of new economic actors in the Cuban economy. Nonetheless, if we consider recent changes and their effects on the system of social relations that sustains the productive and working spaces in Cuba, we can highlight two developments in particular: Firstly, the emergence and legitimization of new forms of capital-labour relations based on the transformation of the property system, and secondly, the prevalence of bureaucratic and centralized logics of labour relations. Together with the pre-existing, long-standing systemic crisis ${ }^{4}$ of the state sector in the Cuban economy, these factors have drastically diminished the effectiveness of a system of labour institutions designed to ensure the rights of the working class. It is important to note that, although the update officially started in 2011, this reform process cannot be understood outside the context of the crises and readjustments faced by Cuban society since the late 1980s, which widely impacted the national socio-productive sphere.

With the transformations of the past three decades, the Cuban model of labour relations, ${ }^{5}$ developed since 1959, has also been compromised. Indeed, there had never been a transition towards truly collective ownership in Cuba, with the empowerment of the labour collective as the real manager of production and property (and without the intervention of the state apparatus). Already in the early years of the Cuban Revolution, trade unions began to take on strong state-corporatist overtones, based on the socialist state enterprise and the bipartite relationship enterprise-workers, in which unions represent both the state and the working class. In this context, Cuban trade unions became the transmission belt of the Communist Party of Cuba, i.e., a channel for ideologies and labour practices with a scope of action predominantly limited to

\footnotetext{
${ }^{3}$ Mainly related to the crisis experienced in the 1990 s due to the fall of the socialist bloc. This resulted in an almost total loss of the Cuban international market and the correspondingly large impact on production capacities and thus on the supply of goods and services within the country.

${ }^{4}$ This crisis is now not only expressed in terms of a tendency towards technological obsolescence and low productivity, but also in a productive cycle that does not allow the use of the national economy's real assets, such as a qualified labour force, the possibilities of productive chains, and the insertion in national and international markets.

${ }^{5}$ Understood as the system of power relations established between capital and labour, and where the state plays a mediating role in the process of building rights within this relationship. As a model, it represents the configurations of the relations between the different actors and serves as an explanatory basis for the establishment of labour agreements.
} 
processes of unionization and membership management, the socialization of workers and the promotion of socialist principles of labour. Moreover, the very term labour relations was basically erased from Cuban scientific, political and legal discourses.

Hence, the Cuban model of labour relations evolved into a system that can be summarized, in terms of participation, as highly centralized by the state regarding both resources and strategic and operational decisions. As such, the model expresses the basic contradiction of the Cuban property system, in which property was never really socialized and the expropriation of the wealth generated by the workers, i.e., the exploitation of wage-labour, has been legitimized. Moreover, this contradiction is expressed in institutions that systematically curtail active labour participation, either through normative inefficiency (as the design of the model does not ensure participation), or because participation takes place through other channels (non-labour participation structures, e.g., on the community level or in mass organizations). The equalization of social property with state ownership resulted in vertical decision-making structures and a trade union unable to represent workers in collective negotiations. Ultimately, ignoring a continued exploitative situation based on salaried work - even if in conditions of (state-)socialist management - also meant ignoring the possibility of conflict among the principal actors of labour relations, which further limited the possibilities of union action.

This historically determined reality is compounded by the socio-economic transformations that have taken place in the country since 2011. As described above, socio-economic restructuring in Cuba is an ongoing process that, although the update officially began in 2011, has been developing since before 1990 through successive reforms that had already altered the country's productive sphere. However, these reforms have not been accompanied by a well-thought-out reformulation of labour relations. These have been strongly marked by a static trend in the trade union model developed by the Workers' Central Union of Cuba $(C T C)^{6}$, which has kept its structural and functional premises unchanged. Indeed, it is true that the update is not the first substantial restructuring of the socio-economic dynamics that have characterized the Cuban development model. ${ }^{7}$ But with the current reform process, the state has given impetus to important development processes of non-state forms of property and labour management. This has led to the proliferation of new sectors in the economy and, consequently, to the emergence of new actors in Cuban labour relations: so-called mixed companies (mainly joint enterprises with both national and foreign capital), non-agricultural cooperatives, as well as the actors of Cuba's relatively small but growing private sector. The latter includes self-employed people and owners of small businesses (known as the economic area of cuentapropismo), as well as (very few) companies with entirely foreign capital.

These emerging economic sectors and actors also present new challenges for Cuban trade union action, which, under the aegis of the CTC, has been characterized by a practice of state-

\footnotetext{
${ }^{6}$ The Central de Trabajadores de Cuba (CTC) is the country's sole representative of the branch unions in the Cuban economy. It represents the continuity of the national trade union practice since the 1930s, which is class-based and has been moving towards a more state-corporatist projection based on the particularities of the Cuban model. At present, 16 national unions are grouped within this trade union centre by branch of the economy. The CTC is represented at the highest levels of government, participating in the main spaces of government management in the country.

${ }^{7}$ Examples of former restructuring processes are the adoption of the System of Management and Planning of the Economy (SDPE) in the 1970s and the Process of Rectification of Mistakes and Negative Trends in the 1980s, as explained in footnotes 10
} and 12 . 
corporatist trade unionism under the logic of state management of the economy. It is true that, in view of the reform process and the new socio-productive situation in Cuba, there are ongoing attempts to develop trade union policies that include these new actors in Cuban labour relations. However, these policies are characterized by mechanical logics that do not favour trade union participation in the newly created labour sectors because they do not recognize the particularities of their structure and functioning that are distinct from the state sector (for example property relations, the nature of incomes and salaries, or access to and the use of technology).

To summarize, since the 1990s, Cuban labour relations have been going through a process of structural dynamization towards a multi-stakeholder and multi-sectoral society. In a bestcase scenario, the emergence of new actors and new relational structures between capital and labour could contribute to the configuration of new strategies of union action within the Cuban socialist project and allow for the construction of novel spaces of confrontation. So far, however, it seems that these changes have only made the existing Cuban trade union model less effective. What is more, the socio-productive relations of non-state forms of labour and property management are characterized by a diversity and dynamism that have still not been covered by the regulatory apparatus. This also led to the precarisation of labour in different sectors of the $\mathrm{Cu}$ ban economy - a precarisation that is reflected, for example, in a lack of labour rights in the socalled non-state sector, or in the decreased purchasing power of wages in a large part of the state sector, as described below.

\section{Principles and Realities of Cuban Labour Policies}

The stateization process of the Cuban economy, which began with the nationalization of the main means of Cuban economic production in the early 1960s, was accompanied by an important decapitalization of the country, including both financial and so-called human capital, as a large proportion of investors and skilled workers left the country during the first years of the Revolution. New social and labour policies were developed to give support and legitimacy to the then-proposed development model, to respond to national and international political and economic dynamics, and to allow for the control of national labour resources. To this day, these policies have taken into account almost all contemporary principles of the Decent Work Agenda. However, the effectiveness of said policies, which aim to ensure the (socialist) principles of (decent) work in Cuba, is largely impaired by the socio-economic developments of the country, as well as by its framework of labour relations.

The principle of full employment, in force until the early 2000s as one of the fundamental pillars of Cuban social and labour policy, is perhaps its most controversial one. It was based, firstly, on the strong emphasis on social development, and secondly on the high degree of state control over national resources (material, financial and human). In practice, the application of this principle translated into political strategies driven by the social deficit inherited from previous governments (low and/or unequal levels of education, health coverage, territorial development, etc.). These strategies eventually generated tensions between social and economic development priorities, resulting, for instance, in the goal to strike a balance between the objective of safeguarding employment and at the same time promoting innovation, efficiency and productivity. Together with the structural crisis that began in the late 1980s/early 1990s (and 
the transformations carried out to overcome this crisis), this finally led to the disappearance of full employment as a principle and practice of Cuban employment policy. ${ }^{8}$

Cuban employment policy and strategy strongly emphasized educational development. Educational policies aimed to reconfigure the qualification structure of the national labour force so that it could cope, on the one hand, with the low availability of qualified labour on the national level in the first years of the revolution, and on the other hand, with the need to develop the most socio-economically disadvantaged territories. In practice, however, the structural tensions linked to full employment also affected educational strategies and developments, generating a high supply of qualified workers not linked to installed and/or available production capacities. Nonetheless, the emphasis on education allowed for the development of so-called human capital that represents a potential asset in the contemporary Cuban development model, as well as a comparative advantage regarding the country's integration into the international economy.

The freedom to choose a job and equal opportunities to access it without discrimination of any kind are two further principles ${ }^{9}$ that appear controversial both in the policy design and in practice. Very closely linked with the principles of full employment and educational development, they cannot be understood outside of a system of labour insertion where the educational level represents the fundamental motor of social mobility, at least until the end of the 1980s. Thus, the freedom to choose and access employment without discrimination, in a context of almost absolute state control over labour resources, was mainly equated with the freedom to choose an education and a professional career - which, in turn, was limited by the capacity of the state to offer jobs. Finally, two other principles are worth mentioning here, namely the prohibition of child labour (with an official working age of 18 , and special legislation for adolescents between the ages 15 and 18 who have completed their studies in professional or vocational education), as well as health and safety in the workplace. The latter is one of the least institutionalized principles within politics, which is mainly due to a lack of control and development mechanisms.

It must be stressed that the development of each of these principles is closely related to the system of labour relations that prevailed in the country until the mid-1990s at least. The state as guarantor of each of these relation ${ }^{10}$ has played a constant and important role for the development, the achievements, but also the deficiencies of this system. Achievements that are sustained until today are linked, first and foremost, to access to employment (both in quantitative and qualitative dimensions), which is considered a citizen's inalienable right and which is based on inter-institutional relations that follow a logic of state assurance and planning. The deficiencies of the system had already been apparent in the 1970s/80s, when the statist ownership model was enforced, but they were undoubtedly entrenched during the structural crisis of the 1990s. Over time, the lack of a de facto appropriation and socialization of both the means of production

\footnotetext{
${ }^{8}$ Although the official disappearance of this principle from Cuban employment policy is attributed to the year 2010 (see, for example, Echevarría, Rojas and Tejuca 2019: 151), the pursuit and realization of this principle was affected much earlier in practice.

${ }^{9}$ The principle of equal pay for equal work is also closely linked to this.

${ }^{10}$ From the point of view of generating the necessary productive capacities and labour resources, but, more importantly, also from the perspective of generating the institutional frameworks for the functioning (and control) of this system of relations.
} 
and of the wealth created by the workers contributed to the development and institutionalization of bureaucratic mediation, which ended up undermining the sustainability of employment policies and realities, as well as economic development in general.

In addition to such policy deficiencies, a set of problematic dynamics and processes linked to the realm of work has become apparent in the past decades. In some cases, these dynamics and processes resulted from the crisis of the 1990s and the loss of trade relations with the Socialist Bloc. In other cases, they were consequences of the very strategies designed to face this reality. One of the main problems resulting from the crisis was the decline of general employment levels by up to $15 \%$ - including a significant decrease in state employment due to the decapitalization of this sector (Izquierdo 2016). We may state in this regard that although the decline in employment was already announcing itself during the so-called Process of Rectification of Mistakes and Negative Trends ${ }^{11}$ in the last five years of the 1980s, it was certainly aggravated by the crisis of the 1990s.

One of the main strategies to face the new realities after the end of the Soviet Union was manifested by what could be called a process of de-stateization, i.e., a gradual contraction and retreat of the state in the national economy. This process began in the 1980s with the opening up to self-employment, the creation of joint ventures and the transition of most state-owned farms to the cooperative sector. This process has been ongoing ever since and has certainly been intensified with the structural readjustments of the update of the socio-economic model during the past decade. The exit strategies of the state contributed to reversing some of the impacts of the crisis in the 1990s (some of which continued into the $21^{\text {st }}$ century) and have improved employment rates, especially in the newly created (or revived) sectors of the economy. At the same time, these strategies presented new challenges for an already unstable social and labour policy. One of the main challenges was the applicability of the above-described principles in a context where the state was losing its capability to ensure productive capacities and therefore opened the economy to new actors. With this process, there emerged social and labour dynamics that were alien to many of the logics underlying Cuban employment policy and its essential principles. In its old configuration, the state remained limited in its capacity to act and to generate new institutional dynamics and regulations, especially regarding informality and informal work. This has led to high levels of labour precarisation, particularly expressed in: high unemployment rates (especially regarding youth, female and urban unemployment); the worsening of the tensions between available production capacities and the qualification and geographic location of the workers; the deregulation of labour relations; a strengthening of the informal sector and an increase in informal economic practices in the 1990s.

Today, even if certain levels of economic revival and the maintenance of the fundamental principles of social and labour policy are seen as indisputable, the precarisation of work remains visible in different areas within the state sector. This is, on the one hand, closely linked to the inability of the jobs in this sector to ensure the reproduction of workers (as human beings) in areas that are not considered to be motors of the economy. On the other hand, it is also linked to the conditions and organization of work in this sector. Precarious working conditions are also becoming increasingly evident in non-state sectors but here, they are rather linked to the

\footnotetext{
${ }^{11}$ A political reform campaign to redirect socio-economic policies and to find a middle course between the "idealist errors" of the 1960s and the "economic errors" of the 1970s (Mesa-Lago 1994: 127).
} 
normative and organizational aspects of work. What appears to be fundamental here, is the fact that the state is losing control over the real applicability of employment policy by relinquishing part of its representative role within the capital-labour relationship to the non-state sectors of the economy.

In essence, Cuban social and labour policy continues to maintain its founding principles with greater or lesser levels of institutionalization. Unfortunately, the Current Labour Code, enacted in 2014 (ANPP 2014), has even weakened many of the above-discussed principles of Cuban employment policy and has not ensured sufficient progress in labour relations. Although the code gives recognition and legitimacy to the rights of workers and trade unions under the conditions of the above-outlined contradictions, it conceives of workers as subordinate subjects and conceals their practical possibilities of action and control - to which they are constitutionally entitled. The Code is not expected to be changed until at least three years from now (at the time of writing, i.e., spring 2020) and will thus in the meantime increase the contradictions and institutional gaps Cuban labour policy is facing today.

This being said, in the context of changing socio-economic conditions and the ongoing reforms, further principles and measures have been included in Cuban employment policy over the past years. Some examples are: an increasingly territorial vision of employment policy based on the development of territorial employment programs; the strengthening of the workforce for emerging economic sectors (tourism, biotechnology and pharmaceutical industry); business resizing and rationalization of excess personnel under conditions of salary assurance (according to the time of services provided); the development of training programs regarding the re-qualification of workers who have faced processes of staff rationalization and workers who are newly looking for jobs; the assurance of job placement for higher education graduates (and protection of those who graduate from technical-vocational education); the creation of special employment programs aimed at the most vulnerable groups of the employment population (such as disabled persons, single mothers and other population segments that require it); guaranteeing the retention of qualified workers in key sectors (from a social point of view), such as education and public health (particularly in terms of rehiring regarding the former and salary regarding the latter).

However, we need to stress again that the conditions for social dialogue between the fundamental actors of the Cuban model of labour relations continue to be problematic. In view of the diversification of these actors in contemporary Cuba, this appears to be the basis of the contradictions that sustain the ineffectiveness of this social and labour policy in terms of the fight against the precarisation of labour. To further illustrate these contradictions, we will, in the following, discuss the examples of wage policies and gender equality measures - two areas in which the political claims and principles of decent work seem to be particularly at odds with Cuban everyday realities - in more detail. 


\section{Wage policy}

In accordance with the second pillar of the Decent Work Agenda ${ }^{12}$, the principles promoted by Cuban wage policies since the early years of the revolution have formally aimed to meet decent wage criteria - within the particular framework of a national economy based mainly on state property, as explained in the previous sections. However, the reality of Cuban wages is far more complicated, especially in contemporary Cuba.

The salary system of the Cuban state sector - which, according to official statistics (ONEI 2019), still employs around two-thirds of the Cuban labour force - is based on standardized and centrally fixed wages. Historically, these can be traced back to the introduction of unified wage scales in the early 1960s. These scales, as well as the corresponding policies, have been slightly changed and adapted in the past decades. However, the system's basic principles have remained steady over time: The core of the wage system is formed by a minimum wage, a unified wage scale at the national level and two basic forms of payment: payment according to time and payment according to performance (Galtés 2017: 67). Although the attempts towards complete wage equalization and total demonetization from the late 1960s (e.g. Hernandez/MesaLago 1971) were abandoned in the $1970 \mathrm{~s}^{13}$, Cuban state wages are until today considered to be relatively low in international comparisons and to present little differentiation between different categories of occupation. However, it is often stressed that these features of Cuba's salary system have to be considered against the backdrop of the country's social policy tradition, that is, free and universal education and social protection services, subsidies (e.g., for electricity, communication and culture), and the distribution of food and basic consumer goods (e.g. Dominguez 2017).

As described previously, socio-economic developments in the past decades have presented new challenges for Cuban institutions and policies, especially in terms of social protection and decent wages. While prices increased dramatically during the crisis of the 1990s, real wages are estimated to have fallen between 70 and 90\% (Mesa-Lago/Pérez-López 2014: 14; Yaffe 2012: 37). As a result, labour and income in economic spheres outside of the state sector (i.e., the private sector, mixed enterprises and the cooperative sector in the formal economy, but also informal work, underground and illegal activities) became increasingly important. The introduction of a dual currency system ${ }^{14}$ and the boosting of the tourism industry to combat the effects of the crisis contributed to the socio-economic division in these different sectors and spheres.

In 2010, in view of the impending update of the economy, the Cuban government had announced the dismissal of a large portion of state sector employees. Although these layoffs

\footnotetext{
${ }^{12}$ Which specifies that measures of social and labour protection should include "[p]olicies in regard to wages and earnings [...] designed to ensure a just share of the fruits of progress to all and a minimum living wage to all employed and in need of such protection" (ILO 2008: vii).

${ }^{13}$ Notably with the adoption of the System of Management and Planning of the Economy (SDPE), which was based on the Soviet model.

${ }^{14}$ Based on the National Cuban Peso (CUP) and the US-Dollar; in 2004, the latter was replaced by a distinct convertible currency, the Convertible Peso (CUC).
} 
eventually occurred more slowly and on a smaller scale than originally planned ${ }^{15}$, it is estimated that throughout the past decade, more than half a million workers were dismissed from the state sector (e.g. Bye 2020: 33). Those who have continued to be state-employed often rely simultaneously on jobs and incomes outside of the state sector (see, e.g., Echevarría /Tejuca 2017; Galtés 2015). This is what Feinberg (2016) labels the GESPI category: government employees with a significant private income. He makes a conservative estimate of this category at 10 to $20 \%$ of the public workforce (Feinberg 2016: 111). Certainly, few workers could live on their state wages without relying on other sources of income - whereby various forms of material and immaterial income supplements come into play (Ritter 2006). It is worth noting in this context that for many Cuban households, remittances have become an equally or more important source of income than work-related incomes, which contributes to poverty reduction, but also widens inequalities within society (Barberia 2017). ${ }^{16}$ Regarding the overall situation of social protection, health care and education, it is true that the Cuban state has, until today, maintained universal access to basic goods and social services, but their availability and quality has declined (Dominguez 2017).

In the context of little available statistical data, the dual currency system, and the close entanglement of wages, social services, subsidies and food rationing, it is difficult to assess the purchasing power of state salaries. Nonetheless, until today, most Cuban incomes, and especially wages in the Cuban state sector, are considered to be below the subsistence minimum. In the past years, this has been repeatedly acknowledged even by Cuban political leaders, who, for instance, stated that "it is true that the salary does not meet all the needs of the worker and his family" (Castro 2014), and that salaries are "insufficient" to cover the necessities of the workers (e.g. EFE 2019). In the past decade, there have been wage increases in both the state enterprise system and in the public sector, and compensation schemes were further diversified (emphasizing, for example, performance-related pay). However, although nominal average salaries have grown in the past decade, this has hardly been the case for real wages, which are considered to "not cover the cost of Cuban daily life" (Echevarría/Tejuca 2017: 156). According to Togores/García (2003: 4), until the 1980s, wages in the state sector accounted on average for about three-quarters of household income, while by the 1990s, they represented only slightly more than half of it. Vidal (2016: 154) states that the purchasing power of the real average state salary in 2013 represented 25\% of the 1989 salary purchasing power. In 2016, according to "personal and extra-official information provided by then Minister of Economy Murillo [...] a family of four with two breadwinners would cover only $25 \%$ of the family's basic needs through their

\footnotetext{
${ }^{15}$ In the course of the year 2010, different government officials provided varying information as to the planned number of layoffs, which ranged from 1,3 to 1,8 million employees (Bye 2020: 32). In accordance with the objectives of the reform process, the workers that were actually laid off from the state sector are supposed to be absorbed by the growing mixed, cooperative and private non-state sectors. Thus, the dismissals went hand in hand with, for example, the extension of licenses for cuentapropistas (self-employed people and owners of small businesses). For those workers who did not immediately find a new occupation, compensatory measures were provided in the form of a partial and temporary salary replacement and support through the social welfare system (Mesa-Lago/Pérez-López 2014: 124).

${ }^{16}$ The social structure resulting from this income situation is commonly interpreted as an inverse pyramid (e.g. Galtés 2017; Luis 2017). In a nutshell, the term is used to describe disconnections (or, in normative terms, misconnections) between the three parameters qualification, work and income. The inverse pyramid is in turn seen as a cause for low productivity, working motivation and a brain drain within the Cuban economy.
} 
average incomes" (Bye 2020: 86). ${ }^{17}$ Anaya/Garcia (2018) estimate basic expenses for Cuban urban families of three, accounting for subsidies and food rationing. The authors conclude that in 2016 , an equivalent of two to three average wages in the state sector - or nine to ten minimum wages $^{18}$ - was needed to cover the estimated amount of such basic expenses. This does not take into account additional expenditures, which are part of everyday Cuban life (household equipment, repair works, internet, etc.).

Wage policy (together with the abolition of the dual currency system) has been highlighted by Cuban political leaders as one of the priorities of the current reform process. The guidelines of the Update, the Lineamientos de la Política Económica y Social, tackle this only in a very general manner, stating the aim to

restore the role of work and the income obtained from it as the main way to generate quality products and services and increase production and productivity, and to achieve the satisfaction of the fundamental needs of workers and their families. (PCC 2017: 28)

In the last few years, different measures and reforms have been introduced to combat some of the above-described issues related to wages and incomes in contemporary Cuba. They mostly concern regulations about employees in the state sector, such as recent increases in minimum salary (from 225 to 400 Pesos per month, the latter being equivalent to about 16 US dollars), or the wage increases for workers in the public sector in 2019. Basic operating modes of the payment and material stimulus systems within the state enterprise system have been redefined in the Resolution No. 6/2016 of the Ministry of Labour and Social Security (MTSS) and Resolution No. 19/2017 of the Ministry of Finance and Prices (MFP). Galtés (2017: 99) counts among the advantages of these reforms that these eliminate administrative restrictions on wages and allow for simultaneous payment systems (piece-rate and performance-based), as well as for a certain degree of autonomy for state enterprises regarding the distribution of wages. At the same time the author criticizes, among other things, that the resolutions generalize salary penalties and that the distribution of wages among the workers is deregulated and left to the managers of the firms. She also criticizes that the formal requirement of the participation of workers and unions in the annual approval of payment systems is not granted in reality.

To better understand these remarks, it is important to note that the wages of many employees in state enterprises are divided into a basic wage and a so-called stimulus (estimulación), depending on the achievement of (mainly centrally) planned and defined indicators. The fluctuations in the stimulus (which may change monthly, in a range between zero to three times the basic wage of a worker) represent a major uncertainty for workers. Díaz/Echevarría (2017: 234235) stress that sanctions, in the case of non-achievement of the indicators (which are assessed at the company level and not individually), collide with one of the basic principles of the conception of salary payments. ${ }^{19}$ This principle notably conceives of salaries as the expression of the quantity, the quality of, and the time dedicated to work. Referring to Resolution No

\footnotetext{
${ }^{17}$ Here, the term "average incomes" seems to refer primarily to (state) wages, although it is not clear whether food rations are included (see Bye 2020: 101).

${ }^{18}$ Based on average and minimum wages for the year 2016, namely 740 CUP (average wage) and 225 CUP (minimum wage).

${ }^{19}$ Articulated, for example, in the Cuban Labour Code (Asamblea Nacional del Poder Popular 2014: 454).
} 
$138 / 2017$ of the MFP, these authors also criticize that the income of the workers is being sanctioned in a twofold manner (via salaries and via stimuli) in the case of non-achievement of the indicators. They further note that workers do not actively participate in the determination and approval of these indicators and critically highlight that compliance with the indicators does not always lie directly in the hands of the firms, and even less so in the workers' hands.

The previous reflections on the question of decent wages in contemporary Cuba only tackle some main issues relating to wages in the state sector. Although these are closely linked to wage and income-related issues in other sectors, and although some steps have been taken in recent years to regulate wages in the non-state sectors of the economy, many observers criticize that there are still major gaps in this area. As Galtés (2017:65-67) notes, the current labour code and corresponding legislation and resolutions provide, to some extent, norms for wage guarantees and social protection of workers in non-state areas. Nevertheless, she also stresses that the setting of salary levels in these areas does not follow the same rules as the state sector and is perceived to be much more flexible and less regulated, eventually resulting in a widening of the gap between state salaries and incomes from other sectors. This equally applies to social protection issues. Yet, it is difficult to assess the question of decent wages in some parts of the non-state sector, especially due to a lack of data. We, therefore, confine ourselves here to highlighting the gaps between the state- and non-state sectors, as well as the important loopholes in the promotion of decent wages in the informal economy.

Nonetheless, we hopefully managed to illustrate some of the contradictions of the Cuban model outlined in the previous sections. Indeed, fair wages and income from work, as well as legislation on minimum wages (as stipulated by the ILO's criteria to realize decent wage conditions) have been promoted in Cuba since the beginning of the Cuban revolution and are emphasized in the political discourse as part of the current reform process. However, as wage policy - like other areas of employment policy - faces the contradictions inherent in the conception of the Cuban production and property systems, it presents important deficiencies and does not guarantee a real appropriation of the wealth generated by the workers. Before moving on to a general conclusion on this matter, we will shortly address the topic of gender equality in the context of this contradiction.

\section{Gender equality measures}

In order to apply a "gender equality lens" (ILO 2008: 1) and to assess womens' work opportunities and working conditions in Cuban labour policies and realities, we will, in the following, first examine issues of decency (or indecency) of female work in a more narrow sense of core labour standards in the so-called productive sphere. Second, we will refer to a broader conception of the notion of decent work and take a short look at unpaid labour in the so-called reproductive sphere.

Gender equality is said to be a major objective of Cuban politics since the early years of the revolution in the 1960s. It is anchored in the Cuban Constitution (Constitución de la República de Cuba 2019), as well as in labour, social and family legislation and policies. According to the OECD's Social Institutions and Gender Index (OECD 2014a), which addresses de jure and de facto situations of discriminatory social institutions, Cuba is among the countries with very low levels of gender discrimination in social institutions. However, if we look at female labour force 
participation in the realm of paid work, official numbers on the employment gender gap in Cuba are very similar to the global gender gap, ${ }^{20}$ with $49.5 \%$ of Cuban women employed, compared to $76.9 \%$ of Cuban men (ONEI 2019). ${ }^{21}$ In the Cuban state sector, women are still relatively well represented (1.404 million women of the total 3.067 million labour force in 2018; see ONEI 2019). The proportion of highly qualified women in different areas and professions of the state sector is described as relatively high, and their representation in political and other important decision-making functions is often emphasized. ${ }^{22}$ Nonetheless, Cuba is not completely exempt from the phenomenon of gendered occupational segregation, as patterns of educational choices seem to suggest: to date, Cuban women are over-represented in so-called social courses of study and less oriented towards technical and agricultural careers (Echevarría et al. 2019).

As described above, the current developments in Cuba come along with new tensions and problems regarding occupational security, wages, and social protection - and women are particularly affected by these developments. Taking the example of the layoffs in the state sector in the past decade, Lara Junco (2015) notes that between 2010 and 2013, the Cuban state dismissed almost 62,000 women, compared to about 4,000 men. Echevarría/Tejuca (2017: 155) mention a slightly lower number of female workers dismissed from the state sector between 2010 and 2014, namely 51,000. As recent numbers of women's share in the non-state sector show (254,700 women, compared to 1.416 million men in 2018; ONEI 2019), the female labour force coming from the state sector has been absorbed less by the non-state sector than the male labour force.

Nonetheless, especially in the often-discussed area of cuentapropismo (self-employed people and owners of small businesses), women's labour participation has been increasing (from 152,000 in 2015 to 197,200 in 2018; ONEI 2019). Assessing decent working conditions in this area of the Cuban economy seems particularly difficult, since it is possible to conceive of cuentapropismo as both a potential for the Cuban economy and, due to a persisting lack of regulation, a threat to basic labour standards and social protection of workers. The return of paid domestic work in Cuba (e.g. Romero 2016; 2019) may serve as an illustration for this, especially with regard to gender-related issues. Historically, after the takeover of the revolutionary government in the 1960s, paid domestic work was frowned upon and almost completely abolished, due to its entanglement with class, gender and racial discrimination. With the rise of cuentapropismo in Cuba at the beginning of the 21st century, there seems to be a resurgence of paid domestic work. As is often the case for activities in the area of self-employment and small businesses in Cuba, the sociodemographic composition of domestic workers is quite diverse and also includes highly qualified women, which is generally perceived as a major threat in terms of brain drain and occupational downgrading. Admittedly, seen from a different angle, many of today's domestic workers find themselves in a relatively good economic situation and enjoy a certain

\footnotetext{
${ }^{20}$ The current global labour force participation is estimated to be about $49 \%$ for women and $75 \%$ for men (ILO 2018a).

${ }^{21}$ Referring to a working age population of women between 17 and 59 years, and men between 17 and 64 years.

${ }^{22}$ Based on national statistics (ONEI 2019; FMC 2016), Echevarría, Rojas and Tejuca (2019) highlight, for example, that more than $70 \%$ of federal prosecutors, presidents of provincial courts and professional judges are female; and that $53,3 \%$ of jobs in the areas of science, innovation and technology are occupied by women, as well as $47,2 \%$ of higher management positions. According to UN Women (2019), in 2019 the proportion of women in Cuban parliament was 53,2\% - the second highest worldwide.
} 
degree of autonomy, which they might not have exercising their original profession, at least not in Cuba's current labour context.

Yet, generally speaking, one of the features of cuentapropismo seems to be the reinforcement of a division into so-called typically female and typically male working activities, which often involve particularly vulnerable working conditions for occupations labelled as typically female (Echevarría et al. 2019). In addition, to date there are more women who do contract work than there are female entrepreneurs - a major explanation for this is women's limited access to seed capital, compared to men's resources of getting such capital (Díaz/Echevarría 2016). As mentioned before, regulation in the area of cuentapropismo remains at a relatively low level, while the precariousness of many activities in this area remains relatively high - with particular deficiencies regarding women's labour, such as lacking rights to paid rest or unpaid leave due to family problems; or even the denial of the right to return to work after maternity leave (Echevarría et al. 2019).

The Cuban legal framework indeed provides basic institutions that should protect working women and ensure gender equality, such as the maternity - and paternity - leaves that should be guaranteed after the birth of a child. By law (Consejo del Estado 2017), working mothers have the right to a pre-natal leave of six, and a post-natal leave of twelve weeks (with a full wage substitution, calculated from the average weekly income from wages received in the twelve months preceding the maternity leave). After that, until the child reaches the first year of life, mothers can either choose to return to work or to care for the child with a wage substitution of $60 \%$ and a job guarantee for the child's second year of life. This leave for early childcare can also be taken by the father. In reality, however, the implementation and realization of these institutions and protection measures must be regarded under the circumstances already discussed above: the regulations apply mainly to the state sector, in which wages are relatively low and are considered to be insufficient to cover costs of living. In other sectors, the regulation and implementation of these institutions seldom exist. It must also be noted in this context that despite the long tradition of promoting gender equality and women's empowerment in Cuba, machismo remains persistent in Cuban daily life. ${ }^{23}$ The number of Cuban fathers who actually take leave for childcare is said to be quite low; some Cuban families might not even know about this possibility. ${ }^{24}$

In Cuba (as in most parts of the world), women continue to perform a majority of the work in the so-called reproductive sphere. According to the OECD (2014b), Cuban women devote about three times as much time to unpaid care work as men. ${ }^{25}$ Indeed, in international

\footnotetext{
${ }^{23}$ For a recent inquiry on machismo (understood as a specific form of patriarchy, mainly in the Latin American and Caribbean context) in contemporary Cuba see, e.g., Fox \& Zagumny (2017). The authors state that traditional Cuban gender roles, expectations and responsibilities continue to manifest in Cuban society, particularly in every-day social interactions and child education.

${ }^{24}$ Unfortunately, we could not find much precise information on this matter. According to UNICEF (2019), between 2003 and 2014, only 125 Cuban fathers took paternity leave. A survey carried out by the Ministry of Health in 2014 (N = 9958 Cuban households) showed that only $18 \%$ of fathers had recently participated in four or more educational activities of their children (aged between 36 and 59 months), compared to 76\% of the mothers (MINSAP 2015). Qualitative research on the matter highlights a persistent traditional division of roles into providing father and affective mother (Da Silva/Guerra 2012: 101).

${ }^{25}$ This number certainly needs to be regarded as a conservative estimate and may only serve as a rough indication, since, unfortunately, there is not much reliable data on the gendered division of labour in Cuba.
} 
comparisons, Cuba is considered to have high enrolment rates in early childhood care and education and is among the countries that have relatively low care dependency ratios (ILO 2018b), which may be interpreted as a certain easing of women's workload. However, Cuban women's double burden of paid and unpaid work also needs to be seen in a context of recurrent economic crises, environmental shocks and scarcity, in which family and domestic chores are highly labour-intensive. To give just one example of research on this matter, Davidson and Krull (2011) have observed a reinforcement of the gendered division of reproductive labour (particularly regarding chores related to food acquisition) in post-Soviet Cuba. Interestingly, the authors note that this gendered division also appears to be reflected in a reinforced and shared discourse on the supposed expertise of women in domestic work. This, in turn, seems to be backed up by the changing policy framework of the past decade, which represents new challenges regarding questions of - paid and unpaid - decent work for women, since the current reform process also seeks to reduce state subsidies and welfare services. It is worth noting that this contrasts sharply with the projected ageing of the population (comparable with demographic developments in so-called first-world countries), which raises the question of who will care for these elderly. ${ }^{26}$ Echevarría et al. (2019) note that these demographic challenges have led to recent policies aiming to raise birth rates and reinforce women's social function in the reproductive sphere. To end this chapter with the words of these authors, in Cuba

paid work is still conceived of as the only work that is valued [...]. This conception explains the scarcity of measures aimed at promoting more equitable gender relations, in which the reproductive space is promoted as an important space for the development of a country. (Echevarría et al. 2019: 153)

\section{Conclusion}

The previous examination of labour policies and realities in Cuba has shown that the promotion of principles associated with the Decent Work Agenda is a necessary, but not sufficient prerequisite to realize conditions of decent work. In the analysis, our goal was to highlight the relations of labour, production and property in the Cuban development model and the resulting (im)possibilities for workers to appropriate their work and the wealth it generates. Furthermore, we addressed some of the institutional logics and problems these relations are based on; as well as the general conception of work that underlies Cuban labour institutions and policies.

As we have attempted to show, Cuban social and labour policies are, until today, based on a socio-economic development model in which social property takes the form of state property. Historically, this model has generated a set of principles, relationships and social and labour policies that seek to propose an equitable appropriation of work (and the wealth it creates) by the workers. However, the current reality of Cuban labour relations and working conditions hardly conforms to this claim. The transformation processes related to the crisis of the 1990s (and its long-standing repercussions and follow-up crises), as well as the strategies designed to face this crisis have led to important institutional loopholes that eventually complicated the system of Cuban labour relations and contributed to the precarisation of working conditions

\footnotetext{
${ }^{26}$ Especially since social security is not very well developed in the area of long-term care in contemporary Cuba.
} 
(including the remuneration of work) in both the state and the non-state sector. In other words, the socio-economic developments of the past decades and the reforms designed to face them, especially the so-called update of the Cuban socio-economic model, have, to some extent, altered Cuban relations of production and property. The state has gradually contracted and retreated as an economic actor in areas where new actors and economic sectors have gained importance.

However, the existence and legitimization of other forms of property than state property and the emergence of new actors in Cuban labour relations have not been covered by sufficient changes in institutions and policies. Conditions for social dialogue between the fundamental actors of Cuban labour relations continue to be problematic, which, in our opinion, represents both a major source of contradictions and an obstacle in the fight against the precarisation of work. Particularly the lacking possibilities for workers' participation in execution and decisionmaking processes appear to be an important obstacle for the maintenance or creation of decent working conditions. This is also reflected in contemporary discussions on Cuban wages, as discussed in this article's section on Cuban wage policy. Moreover, the strong ideational emphasis of the Cuban development model - and its update - on economic development seems to nourish a general conception of work that understands it primarily in economic or commercial rather than in social terms. Particularly the example of women's working conditions and unpaid household and care work seems to substantiate this assumption.

In this respect, Cuba hardly differs from tendencies in other countries around the globe. It appears that the criticism pointing out the ILO's lacking critical stance on the commercialization of labour discussed in the introduction of this article is equally relevant for the Cuban context. Therefore, we would like to emphasize, once again, the importance of such a critical stance when assessing labour policies and realities (in terms of their potential to create and maintain decent working conditions) in any context, also beyond the Cuban case. In our analysis, we stressed the elements of labour and property relations, wealth appropriation, institutions and their (historically formed) logics, as well as ideational and conceptual foundations - such as the conception of work underlying development models and policies. We suggest that these elements can be used as tools for a critical analysis of social and labour policies and can thus be an important complement to other evaluation tools of the Decent Work Agenda. ${ }^{27}$

To conclude, we briefly reflect on some general approaches that could provide a sound basis for decent working conditions in Cuba and that would respond to the challenges discussed in the previous chapters. In our opinion, there is a need for a new regulatory framework that better responds to and involves all actors of the socio-economic system. Mechanisms of economic and political management and action should be adjusted to the new reality and culture of work in contemporary Cuba, which would also require a readjustment of labour organization and execution based on decades of thinking and working within centralist budgets. Further, a revolutionary transformation of the prevailing model of labour relations is necessary, including the generation of new forms of enterprise and labour organization in the state sector that allow for a more participatory model of labour relations. This would require the adoption of a company law that recognizes the decisive authority of workers in the state sector. In the non-state sector, the problematic existence of private economic actors that distance themselves more and more

\footnotetext{
${ }^{27}$ E.g., the Toolkit for Mainstreaming Employment and Decent Work (ILO 2008); or other assessment tools developed in international and national frameworks.
} 
from the (generic and almost euphemistic) category of self-employed workers should be addressed. Workers in the area of cuentapropismo should be made visible as legal entities and as social subjects with very particular socio-productive logics. This would also contribute to the generation of a new model of labour representation and syndicalism that surpasses the existing model of labour relations and that can represent the multiplicity of interests emerging in the consolidation process of a mixed economy.

\section{Acknowledgements}

The authors thank two anonymous reviewers and the editors of socialpolicy.ch for their comments, which helped to establish clarity and improve the manuscript.

\section{Declaration of conflicting interests}

The authors declare no potential conflicts of interest with respect to the research, authorship, and publication of this article.

\section{Funding}

Part of the research for this article was funded by a Doc.CH grant of the Swiss National Science Foundation (Grant no. 184367).

\section{References}

Anaya, Betsy and Anicia García (2018). Gastos básicos de las familias cubanas urbanas dependientes de salarios y pensiones: dinámica reciente. In: Anaya, Betsy and Ileana Díaz (eds.). Economía cubana: entre cambios y desafíos. La Habana: Instituto Cubano de Investigación Cultural Juan Marinello, 6588.

ANPP Asamblea Nacional del Poder Popular (2014). Código del Trabajo de la República de Cuba. Gaceta Oficial de la República de Cuba, Minesterio de Justicia, Gaceta Oficial No. 29, Extraordinaria de 17 de junio de 2014: La Habana.

ANPP Asamblea Nacional del Poder Popular (2019). Constitución de la República de Cuba. Gaceta Oficial de la República de Cuba, Minesterio de Justicia, Gaceta Oficial No. 5, Extraordinaria de 10 abril de 2019: La Habana.

Barberia, Lorena G. (2017). The Impact of Remittances on Poverty and Inequality for Cuba: Lessons from Latin America. In: Domínguez, Jorge I., María del Carmen Zabala Argüelles, Mayra Espina Prieto and Lorena G. Barberia (eds.). Social Policies and Decentralization in Cuba: Change in the Context of 21st-Century Latin America. Cambridge, MA: Harvard University Press, 221-248.

Bye, Vegard (2020). Cuba, From Fidel to Raúl and Beyond. Cham: Springer Nature Switzerland. 
Castro, Raúl (2014). Discurso de Raúl en la CTC: Para distribuir riqueza, primero hay que crearla. Website. Last accessed 22.02.2018 on http://www.cubadebate.cu/opinion/2014/02/22/discurso-de-raulen-la-ctc-para-distribuir-riqueza-primero-hay-que-crearla/\#.WbaNbcaLmUl.

Consejo de Estado (2017). Decreto Ley No. 339 “De la maternidad de la trabajadora”. Gaceta Oficial de la República de Cuba, Minesterio de Justicia, Gaceta Oficial No. 7, Extraordinaria de 10 de febrero de 2017: La Habana.

Da Silva, Denise Quaresma and Oscar Ulloa Guerra (2012). Masculinidades en Cuba: Legitimación de una Dimensión de los Estudios de Género. Revista de Estudios Sociales 42, 93-103.

Davidson, Mélanie Josée and Catherine Krull (2011). Adapting to Cuba's Shifting Food Landscapes: Women's Strategies of Resistance. Cuban Studies 42, 59-77.

Díaz, Ileana and Dayma Echevarría (2016). El emprendimiento en Cuba: un análisis de la participación de la mujer. Entramado 12(2), 54-67.

Díaz, Ileana and Dayma Echevarría (2017). La empresa estatal cubana. Un análisis de las transformaciones del trabajo estatal en el contexto de la actualización del modelo. In: Izquierdo, Osnaide and Hans-Jürgen Burchardt (eds.). Trabajo decente y Sociedad. Cuba bajo la óptica de los estudios sociolaborales. La Habana: Editorial UH, 217-240.

Domínguez, Jorge I . (2017). Introduction: Social Policy and Economic Change in Cuba. In: Domínguez, Jorge I., María del Carmen Zabala Argüelles, Mayra Espina Prieto and Lorena G. Barberia (eds.). Social Policies and Decentralization in Cuba: Change in the Context of 21st-Century Latin America. Cambridge, MA: Harvard University Press, 1-22.

Echevarría, Dayma and Mayra Tejuca (2017). Education and Employment in Cuba: Congruity or Disequilibrium? The First Fifteen Years of the Twenty-First Century. In: Domínguez, Jorge I., María del Carmen Zabala Argüelles, Mayra Espina Prieto and Lorena G. Barberia (eds.). Social Policies and Decentralization in Cuba: Change in the Context of 21st-Century Latin America. Cambridge, MA: Harvard University Press, 139-172.

Echevarría, Dayma, Mirlena Rojas and Mayra Tejuca (2019). Género y trabajo: puntos ciegos de las políticas de empleo en Cuba. Revista de Estudios del Desarrollo Social: Cuba y América Latina 7(3), 148-162.

EFE (2019). Bajos salarios, la mayor preocupación laboral en Cuba. Website. Last accessed 28.02.2020 on https://oncubanews.com/cuba/bajos-salarios-la-mayor-preocupacion-laboral-en-cuba/.

Feinberg, Richard (2016). Open for Business. Building the New Cuban Economy. Washington: Brookings Institution Press.

FMC Federacion de Mujeres Cubanas (2016). Informe Cuba. XIII Conferencia Regional sobre la Mujer. Montevideo: CEPA.

Fox, Brandon and Zagumny, L. (2017). Organizational Approaches to Addressing Machismo and Sexuality in Cuba. Journal of Ethnographic and Qualitative Research 12(3), 97-109.

Galtés, Indira (2015). Diferenciación salarial y productividad en Cuba. Economía y Desarrollo, 153 (Número Especial), 108-125.

Galtés, Indira (2017). Aportes para un rediseño de la politica salarial en el contexto de la actualizacion del modelo económico cubano. Dissertation thesis, Universidad de la Habana: La Habana. 
Hauf, Felix (2015). The Paradoxes of Decent Work in context: A Cultural Political Economy Perspective. Global Labour Journal 6(2), 138-155.

Hernández, Roberto E. and Carmelo Mesa-Lago (1971). Labor Organization and Wages. In: Mesa-Lago Carmelo (ed.). Revolutionary Change in Cuba. Pittsburgh: University of Pittsburgh Press, 209-249.

ILO International Labour Organisation (1944). The Declaration of Philadelphia. Website. Last accessed 25.01.2020 on http://www.ilocarib.org.tt/projects/cariblex/conventions 23.shtml.

ILO International Labour Organisation (2008). Toolkit for Mainstreaming Employment and Decent Work. Country Level Application. Geneva: International Labour Office.

ILO International Labour Organisation (2018a). The gender gap in employment: What's holding women back? Website. Last accessed 11.02.2020 on https://www.ilo.org/infostories/en-GB/Stories/Employment/barriers-women\#global-gap.

ILO International Labour Organisation (2018b). Care Work and Care Jobs. For the Future of Decent Work. Geneva: International Labour Office.

Izquierdo, Onaide (2016). Reconfiguración de las Relaciones Laborales y reajuste del modelo socioeconómico. Retos para el modelo sindical cubano. Estudio de Caso de las formas no estatales de gestión del trabajo y la propiedad en la Habana. In: Emilce Cuda (ed.). Nuevos Estilos Sindicales en América Latina y el Caribe. Buenos Aires: CLACSO, 185-256.

Izquierdo, Osnaide (2017). El concepto de trabajo decente. Fuerzas, críticas y alternativas desde la realidad cubana. In: Izquierdo, Osnaide and Hans-Jürgen Burchardt (eds.). Trabajo decente y Sociedad. Cuba bajo la óptica de los estudios sociolaborales. La Habana: Editorial UH, 107-132.

Lara Junco, Teresa (2015). Cuanto y como trabajan las mujeres en Cuba? Website. Last accessed 11.02.2020 on https://oncubanews.com/cuba/sociedad-cuba/genero/cuanto-y-como-trabajan-lasmujeres-en-cuba/.

Luis, María Josefa (2017). Proyectos de vida y Política de Empleo. Los jóvenes en el proyecto socioeconómico cubano. In: Izquierdo, Osnaide and Hans-Jürgen Burchardt (eds.). Trabajo decente y Sociedad. Cuba bajo la óptica de los estudios sociolaborales. La Habana: Editorial UH, 187-216.

Mesa-Lago, Carmelo and Jorge Pérez-López (2013). Cuba under Raúl Castro. Assessing the Reforms. Boulder: Rienner.

Mesa-Lago, Carmelo (1994). Breve historia económica de la Cuba socialista. Políticas, resutados y perspectivas. Madrid: Alianza Editorial.

MINSAP Ministerio de la Salud Pública (2015). Cuba. Encuesta de Indicadores múltiples por Conglomerados 2014. Informe final. La Habana: MINSAP.

OECD Organisation for Economic Co-operation and Development (2014a) OECD's Social Institutions and Gender Index. Last accessed 11.02.2020 on https://www.oecd.org/dev/development-gender/BrochureSIGI2015-web.pdf.

OECD Organisation for Economic Co-operation and Development (2014b). OECD Gender, Institutions and Development Database 2014. Website. Last accessed 11.02.2020 on https://stats.oecd.org/index.aspx? datasetcode=GIDDB2014.

ONEI Oficina Nacional de Estadística y Información (2019) Anuario Estadistico de Cuba 2018. La Habana: ONEI. 
PCC Partido Comunista de Cuba (2017). Lineamientos de la Política Económica y Social del Partido y la Revolución para el período 2016-2021. Website. Last accessed 05.02.2020 on https://planipolis.iiep.unesco.org/sites/planipolis/files/ressources/ultimo pdf 32.pdf.

Ritter, Archibald (2006). Economic Illegalities and the Underground Economy in Cuba. Website. Last accessed 16.01.2020 on http://steconomice.uoradea.ro/leonardo3/pdf/ECONOMIC\%20ILLEGALITIES\%20AND\%20THE\%20UNDERGROUND\%20ECONOMY\%20IN\%20CUBA.pdf

Romero, Magela (2016). El trabajo doméstico remunerado a domicilio en Cuba. Un estudio de caso en Miramar. Dissertation Thesis. Facultad de Filosofía e Historia, La Habana: Universidad de La Habana.

Romero, Magela (2019). The Restructuring of Labor in Cuba (2008-2016) and Paid Domestic Workers: Broken or Reconstructed Labor Trajectories? In: Rausky, Eugenia María and Mariana Chaves (eds.). Living and Working in Poverty in Latin America. Trajectories of Children, Youth, and Adults, 147177.

Standing, Guy (2008). The ILO: An Agency for Globalization. Development and Change 39(3), 355-384.

Togores, Viviana and Anicia García (2003). Algunas consideraciones acerca del acceso al consumo en los noventa, factores que lo determinan. La Habana: Centro de Estudios de la Economía Cubana.

UN WOMEN (2019). Facts and Figures: Leadership and Political Participation. Website. Last accessed 29.05.2020 on https://www.unwomen.org/en/what-we-do/leadership-and-political-participation/facts-and-figures.

UNICEF United Nations Children's Fund (2019). Padre desde el principio. Website. Last accessed 29.05.2020 on https://www.unicef.org/es/historias/padre-desde-el-principio.

Vidal, Alejandro (2016). Cuba's reform and economic growth: a comparative perspective with Vietnam, Journal of Economic Policy Reform 19(2), 148-165.

Yaffe, Helen (2012). Che Guevara and the Great Debate, Past and Present, Science \& Society 76(1), 1140. 